\title{
Correction: COVID-19 and the academy: opinions and experiences of university-based scientists in the U.S.
}

Timothy P. Johnson (1), Mary K. Feeney, Heyjie Jung, Ashlee Frandell, Mattia Caldarulo, Lesley Michalegko, Shaika Islam \& Eric W. Welch

Correction to: Humanities and Social Sciences Communications https:/doi.org/10.1057/s41599-021-00823-9, published online 17 June 2021.

The original paper lacked a clear statement on ethical approval and informed consent. The following statements have now been added to the paper to provide additional clarity for the reader:

\section{Ethical approval}

The questionnaire and methodology for this study was approved by the Human Research Ethics committees at Arizona State University (Study \#00011868) and at the University of Illinois at Chicago (Protocol \#2020-0470).

\section{Informed consent}

All individuals invited to participate in the study were provided a statement of informed consent. The informed consent language clearly explained their rights as a research subject/participant. By entering the survey individuals affirmed their consent.

Published online: 15 November 2021

\footnotetext{
(c) Open Access This article is licensed under a Creative Commons Attribution 4.0 International License, which permits use, sharing, adaptation, distribution and reproduction in any medium or format, as long as you give appropriate credit to the original author(s) and the source, provide a link to the Creative Commons license,

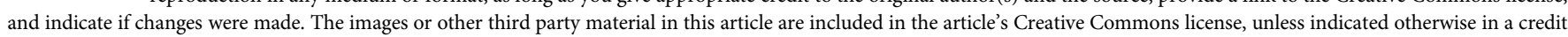
line to the material. If material is not included in the article's Creative Commons license and your intended use is not permitted by statutory regulation or exceeds the permitted use, you will need to obtain permission directly from the copyright holder. To view a copy of this license, visit http://creativecommons.org/licenses/by/4.0/.
}

(C) The Author(s) 2021 